\title{
Employees Personality of Intrapersonal and Interpersonal on Emotional Intelligence
}

\author{
Dr. V. Vetrivel \\ Assistant Professor, Department of Business Administration, \\ Theivanai Ammal College for Women (Autonomous), Villupuram, Tamil Nadu, India
}

\begin{abstract}
The aim of this paper is to investigate the dimension of personality of differently able employees on Emotional Intelligence such as Intrapersonal and Interpersonal skills. The descriptive interview schedule is found to be the suitable research tool for making this paper. The sample was drawn from differently able person working on Public and Government sectors in kanchipuram district. The sample size of the present study is 486. Multiple regression analysis is used to measure the linear association between the dependent and independent variables. It is found that Personality dimensions of differently able employees are influencing the interpersonal skills of EI.
\end{abstract}

KEY WORDS: Emotional intelligence, interpersonal skills, intrapersonal skills

\section{INTRODUCTION}

The interpersonal and intrapersonal skills are, to some extent, innate in each person or acquired at an early age, job seekers and those looking for promotions can take steps to improve their skills and thereby make themselves more valuable to an organization. The word "intelligence" is as old as human existence and symbiotically associated with thinking skills that distinguish an individual from another and most importantly a predictor of life adjustment in the society. When psychologists began to write and think about intelligence, they focused on cognitive aspects, such as memory and problem-solving. However, there were researchers who recognized early on that the non-cognitive aspects were also important. For instance, David Wechsler defined intelligence as "the aggregate or global capacity of the individual to act purposefully, to think rationally, and to deal effectively with his environment". As early as 1940 he referred to "non-intellective" as well as "intellective" elements, by which he meant affective, personal and social factors. Furthermore, as early as 1943 Wechsler was proposing that the non-intellective abilities are essential for predicting one's ability to succeed in life. Wechsler was not the only researcher who saw non-cognitive aspects of intelligence to be important for adaptation and success. Robert Thorndike was writing about "social intelligence" in the late thirties (Thorndike \& Stein, 1937). Unfortunately, the work of these early pioneers was largely forgotten or overlooked until 1983 when Howard Gardener began to write about "multiple intelligence". Gardener (1983) proposed that "intrapersonal" and "interpersonal" intelligences are as important as the type of intelligence typically measured by IQ and related tests.

Emotional intelligence has proven a better predictor of future success than IQ. Emotional intelligence of a person increases his confidence, curiosity, intentionality, self control, capacity to communicate and ability to cooperate (Goleman, 1995). According to Goleman (1995), "Emotional intelligence, the skill that helps in harmonizing, should become increasingly work place asset in the years to come." People high on EI are better able to pick up nonverbal cues in a communication procedure. People who cannot marshal some control over their emotional life fight inner battles that sabotage their ability for focused work and clear thought (Druskat \& Wolff, 2001). Emotional deregulation can lead to work and relationship difficulties and is associated with clinical problems such as anxiety and mood disorders. Deficits in emotional intelligence can create serious problems in our relationship and influence our physical health. 
Personality plays one of the significant roles in determining the behavioral and communication pattern of an individual with his fellow employers and senior colleagues. Besides, helping you to deal with certain situations, personality development is the sole reason behind the individual's behavior at the workplace. Not only does personality development aids in brushing up with the pattern of interaction and grooming individuals to better them, but is also known to boost the caliber and worth of that particular individual; to make them suitable for the organization they are serving for. This paper deals the dimension of personality such as activeness, enthusiasm, trustiness, emotional stability, responsibility, friendliness and decisiveness with emotional intelligence of intrapersonal and interpersonal skills of differently able employees. So there is a need for to identify the influence of personality on emotional intelligence.

\section{Research Methodology}

The main aim of this paper is to investigate the dimension of personality of differently able employees on Emotional Intelligence (Intrapersonal and Interpersonal skills). The descriptive interview schedule is found to be the suitable research tool for making thispaper. The sample was drawn from differently able person working on Public and Government sectors in kanchipuram District.Public sectors were Banks, BSNL and NLC and Government sectors which were covered Schools, Colleges, University, Hospitals, EB, Transport Department, Revenues Department, PWD, Post offices and Municipalities. The sample size was determined as 440. In anticipation of non-response, an additional 10 percentage of the expected sample size was planned. Therefore, the sample size of the present study is 486 . Respondents are coded and data are entered and then analysed using a computer programme called Statistical Package for Social Sciences (SPSS) 20.0 to get inferences. Multiple regression analysis is used to measure the linear association between the dependent and independent variables.

\section{Result and Analysis}

Table 1: Influence of Personality of Differently Able Employees and Intrapersonal Skills on Emotional Intelligence

\begin{tabular}{|c|c|c|c|c|c|c|c|c|}
\hline \multirow{2}{*}{$\frac{\mathbf{R}}{0.772}$} & \multirow{2}{*}{$\frac{\text { R Square }}{0.595}$} & \multicolumn{2}{|c|}{ Adjusted R Square } & \multicolumn{3}{|c|}{ Std.Error of the Estimate } & F & Sig. \\
\hline & & \multicolumn{2}{|c|}{0.583} & \multicolumn{2}{|c|}{0.517} & \multirow{2}{*}{ 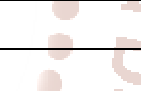 } & 49.409 & 0.000 \\
\hline & $12=$ & $\mathrm{O}$ & Del & alonine & 21 & & 8 & \\
\hline & \multicolumn{2}{|c|}{ Personality } & B & Std. Error & Beta & $\mathrm{t}$ & Sig. & \\
\hline & \multicolumn{2}{|c|}{ (Constant) } & 1.003 & 0.196 & $n-$ & 5.118 & 0.000 & \\
\hline & \multicolumn{2}{|c|}{ Activeness } & 1.031 & 0.089 & 0.940 & 11.567 & 0.000 & \\
\hline & \multicolumn{2}{|c|}{ Enthusiasm } & -0.112 & 0.081 & -0.107 & -1.387 & 0.167 & \\
\hline & \multicolumn{2}{|c|}{ Trustiness } & -0.030 & 0.081 & -0.031 & -0.371 & 0.711 & \\
\hline & \multicolumn{2}{|c|}{ Emotional Stability } & 0.058 & 0.105 & 0.054 & 0.558 & 0.578 & \\
\hline & \multicolumn{2}{|c|}{ Responsibility } & -0.039 & 0.083 & -0.037 & -0.469 & 0.639 & \\
\hline & \multicolumn{2}{|c|}{ Friendliness } & -0.043 & 0.066 & -0.043 & -0.654 & 0.514 & \\
\hline & \multicolumn{2}{|c|}{ Decisiveness } & -0097 & 0073 & -0089 & -1334 & 0184 & \\
\hline
\end{tabular}

Source: Primary data computed*significant at one percent level; **significant at Five percent level; Not - significant

Table 1 depicts the regression analysis of personality and intrapersonal skills on emotional intelligence. It is found from the correlation table that personality has relationship with intrapersonal skills on emotional intelligence. However, considering these seven personalities in finding out which personality is highly influencing intrapersonal skills on emotional intelligence, regression analysis was performed and the results are given in the table 1. Here, intrapersonal skills on emotional intelligence have been taken as dependent variable and personality variables such as Activeness, Enthusiasm, Trustiness, Emotional Stability, Responsibility, Friendliness and Decisiveness are taken as independent variables.

Ho: Personality dimensions of differently able employees are not influencing the intrapersonal skills of EI.

The results of multiple regressions show that the value of co-efficient of regression determination $\left(\mathrm{R}^{2}\right)$ is 0.772, which implies 77.2 percent of the independent 
variables, namely Activeness, Enthusiasm, Trustiness, Emotional Stability, Responsibility, Friendliness and Decisiveness which have influenced the intrapersonal skills on emotional intelligence.

To check whether this $R^{2}$ is statistically significant, ANOVA has been carried out. The $\mathrm{F}$ value obtained is $49.409(\mathrm{P}<0.001)$ and hence it is ascertained that there is significant relationship between dependent and independent variables. Table 1 reveals that independent variables taken for the study have significant values [Activeness $(\mathrm{t}=11.567 . ; \mathrm{p}$ $<0.001)]$.
It is concluded that the most important predictor that affects intrapersonal skills on emotional intelligence is Activeness. In intrapersonal skills on emotional intelligence, those who have Activeness personality give more importance to intrapersonal skills on emotional intelligence. From table 1, the following regression equation is formed.

$$
\text { Intrapersonal Skills }=1.003+1.031 \text { (Activeness) }+
$$$$
0.112 \text { (Enthusiasm) }+0.030 \text { (Trustiness) }+0.058
$$

(Emotional Stability) +0.039 (Responsibility) +0.043

(Friendliness) +0.097 (Decisiveness)

\section{Table 2: Influence of Personality of Differently Able Employees and Interpersonal Skills on Emotional} Intelligence

\begin{tabular}{|c|c|c|c|c|c|}
\hline $\mathbf{R}$ & R Square & Adjusted R Square & Std. Error of the Estimate & F & Sig. \\
\hline 0.771 & 0.594 & 0.582 & 0.51914 & 49.103 & 0.000 \\
\hline
\end{tabular}

\begin{tabular}{|c|c|c|c|c|c|}
\hline Personality & B & Std. Error & Beta & t & Sig. \\
\hline (Constant) & 1.033 & 0.197 & - & 5.251 & 0.000 \\
\hline Activeness & 1.053 & 0.089 & 0.959 & 11.780 & 0.000 \\
\hline Enthusiasm & -0.160 & 0.081 & -0.151 & -1.967 & 0.050 \\
\hline Trustiness & -0.024 & 0.082 & -0.025 & -0.300 & 0.765 \\
\hline Emotional Stability & 0.022 & 0.105 & 0.020 & 0.207 & 0.836 \\
\hline Responsibility & -0.042 & 0.083 & -0.040 & -0.506 & 0.613 \\
\hline Friendliness & -0.009 & 0.066 & -0.009 & -0.139 & 0.890 \\
\hline Decisiveness & -0.082 & 0.073 & -0.075 & -1.124 & 0.262 \\
\hline
\end{tabular}

Source: Primary data computed*significant at one percent level; **significant at Five percent level; Not - significant

Table 2 depicts the regression analysis of personality and interpersonal skills on emotional intelligence. It is found from the correlation table that personality has relationship with intrapersonal skills on emotional intelligence. However, considering these seven personalities in finding out which personality is highly influencing interpersonal skills on emotional intelligence, regression analysis was performed and the results are given in the table 2. Here, interpersonal skills on emotional intelligence has been taken as dependent variable, and personality variables such as Activeness, Enthusiasm, Trustiness, Emotional Stability, Responsibility, Friendliness and Decisiveness are taken as independent variables.

Ho: Personality dimensions of differently able employees are not influencing the interpersonal skills of EI.

The results of multiple regressions shows that the value of co-efficient of regression determination $\left(\mathrm{R}^{2}\right)$ is 0.771 , which implies that 77.1 percent of the independent variables, namely Activeness, Enthusiasm, Trustiness, Emotional Stability, Responsibility, Friendliness and Decisiveness have influenced the interpersonal skills on emotional intelligence.

To check whether this $R^{2}$ is statistically significant, ANOVA has been carried out. The F value obtained is $49.103(\mathrm{P}<0.001)$ and hence it is ascertained that there is significant relationship between dependent and independent variables. Table 2 reveals that two independent variables taken for the study have significant values [Activeness $(t=11.567 . ; \mathrm{p}<0.001)$, Enthusiasm ( $\mathrm{t}=-1.967 ; \mathrm{p}=0.050]$.

It is concluded that the most important predictors that affect interpersonal skills on emotional intelligence are Activeness and Enthusiasm. In interpersonal skills on emotional intelligence, those who have Activeness and enthusiasm personality gave more importance to 
interpersonal skills on emotional intelligence. From table 2, the following regression equation is formed.

$$
\text { Intrapersonal Skills }=1.033+1.053 \text { (Activeness) }+
$$$$
0.160 \text { (Enthusiasm) }+0.024 \text { (Trustiness) }+0.022
$$

(Emotional Stability) +0.042 (Responsibility) +0.009

(Friendliness) +0.082 (Decisiveness) .

\section{Recommendation and Conclusion}

It is concluded that the most important predictor that affects intrapersonal skills on emotional intelligence is Activeness. In intrapersonal skills on emotional intelligence, those who have Activeness personality give more importance to intrapersonal skills on emotional intelligence. in case of interpersonal skills, Activeness and Enthusiasm. In interpersonal skills on emotional intelligence, those who have Activeness and enthusiasm personality give more importance to interpersonal skills on emotional intelligence.

The emotional intelligence of the differently able employees may be developed with the help of the improvement of so many dimensional personality among the differently able employees. In order to improve the Emotional Intelligence among the differently able employees, the organizations are advised to conduct many personality development programmes for the employees. By appropriate training and development programmes, the level of emotional intelligence of the differently able employee may be enriched. A range of programmes may be focused on the development of communication skills.

\section{References}

1. Akintayo, D.I., \& Babalola, S.S. (2012).The impact of emotional intelligence on workers' behaviour in industrial organizations. International Journal of Humanities \& Social Sciences, 4(2), 83-90.Retrieved January 20, 2013, from http://www.ajol.info/index.php/ijhss/article/view/8 6870/76659.
2. Chughtai, A.A., \& Zafar, S. (2006). Antecedents and consequences of organizational commitment among Pakistani university teachers. Applied Human Resource Management Research, 11(1), 39-64.Retrieved December 29, 2011, from http://applyhrm.asp.radford.edu/Volume\%2011/M S\%2011.

3. Ghorbani, M., \& Sani, S.A.B. (2012).Emotional intelligence and personnel organizational commitment. Middle-East Journal of Scientific Research, 11(8), 1100-1115. Retrieved April 12, 2014 from http://www.idosi.org/mejsr/mejsr11(8)12/15.pdf

4. Goleman, Daniel., (1996) "Emotional Intelligence: Why It Can Matter More Than IQ", Bloomsbury, New Jersey, US.

5. Kerr, R., Garvin, J. Heaton, N., \& Boyle, E. (2006).Emotional intelligence and leadership effectiveness. Leadership and Organisation Development Journal, 27(4), 265-279. DOI: $10.1108 / 01437730610666028$

6. Mishra, P.S., \& Mohapatra, A.K.D. (2010). Relevance of Emotional Intelligence for Effective Job Performance: An Empirical Study. Vikalpa, 35(1), 53-61. Retrieved January 15, 2013, from http://www.vikalpa.com/pdf/articles/2010/vol-351jan-mar-53-61.pdf

7. Negoescu, L. (2012). The impact of Emotional Intelligence on the employee's organizational commitment in highly competitive environments (Master's Thesis). University of Amsterdam, Netherlands. Retrieved January 20, 2014,

8. Oliver, C. (1995). Self-injurious behaviour in children with learning disabilities: Recent advances in assessment and intervention. Journal of Child Psychology and Psychiatry, 36, 909-927.

9. Thompson, M. (2014). Soar with confidence. 1st Ed. London, UK: BookBoon. 